\title{
Sciendo
}

Administration, vol. 70, no. 1 (2022), pp. 1-15

doi: 10.2478/admin-2022-0001

\section{Political developments, 2021}

\author{
David Hugh Moore \\ Department of Political Science, Trinity College Dublin, Ireland
}

\section{The Covid-19 pandemic}

Ireland entered 2021 in the midst of the 'third wave' of the Covid-19 pandemic. This third wave was caused by a combination of the easing of restrictions on 1 December 2020, increased social mixing over the Christmas period and a new Covid-19 variant known as the Alpha variant. This variant was estimated to be $40-80$ per cent more transmissible than the original Covid-19 virus, first discovered in late 2019. On 31 December 2020 Ireland recorded a then-record 1,620 newly reported cases. That same day the country entered a Level 5 lockdown (see Moore, 2021). Over the coming days, record daily case numbers were posted several times. On 6 January 2021 the government announced further restrictions, with schools and the construction sector set to remain closed until at least the end of January (see McGee, 2021). By the end of January more cases of Covid-19 had been recorded in a single month than in the whole of 2020, with more than 100,000 cases reported and over 1,000 Covid-19 related deaths (see Department of Health, 2021).

Ireland remained in lockdown throughout the spring. In late April Taoiseach Micheál Martin, TD, announced a timeline for the easing of restrictions. While the country continued to reopen slowly the initial timeline was pushed back due to the Delta variant of Covid-19. The more transmissible variant quickly became the dominant strain of Covid-19 worldwide and led to an increase in the daily case numbers 
in the state. By July the country was posting the highest daily case numbers since the beginning of the year. Despite this the government pushed ahead with the partial reopening of society. On 26 July indoor dining in pubs and restaurants resumed. However, only those who were fully vaccinated, as evidenced by a vaccination certificate, could dine indoors (see Regan, 2021b).

Daily case numbers began to rise in August and September before climbing steeply in October. Remaining Covid-19 restrictions, including the reopening of nightclubs, social distancing, mask mandates and vaccination certs, were due to be eased on 22 October (see Ryan, 2021). Due to the rising case numbers, the reopening of nightclubs was the only measure eased on this day (see 'Taoiseach calls', 2021). On the day nightclubs reopened, the highest daily total of Covid-19 cases since January was reported (see Ní Aodha, 2021). On 3 December, with cases continuing to increase, a new variant of concern, Omicron, was detected in Ireland. Restrictions were reimposed, with nightclubs closing, bars and restaurants reverting to a maximum of six people per table, cultural and sporting events capped at 50 per cent of capacity, and a maximum of four households allowed to meet indoors. Further, the vaccination certificate was extended to gyms, leisure centres and hotel bars. Further, vaccinated individuals entering the state had to show proof of a negative antigen or PCR test (see Regan, 2021a).

In December the highly transmissible Omicron variant quickly became the dominant variant in the state. This led to a steep rise in the daily case numbers. Due to the rising cases, further restrictions were introduced on 20 December on bars, restaurants, live events, cinemas and theatres. The Christmas period saw record daily cases several times. On 30 December a record 20,554 cases were reported, with a further 20,110 on New Year's Eve. Health officials conceded that the true number was likely far higher due to PCR testing capacity constraints (see Health Protection Surveillance Centre, 2021).

Despite the Covid-19 situation in Ireland in 2020, the vaccination programme offered hope that the pandemic would eventually come to an end. The first Covid-19 vaccine was administered in Ireland on 29 December 2020. By the end of January, three vaccines had received approval and were being used in Ireland. These were PfizerBioNTech, Moderna and Oxford-AstraZeneca. In mid March the use of the Oxford-AstraZeneca vaccine was suspended due to a reported side-effect of serious blood clotting in Norway. A few days later the vaccine was reapproved after approval from the European Medicines 
Agency. In midsummer the Janssen single-shot vaccine produced by Johnson \& Johnson was approved for use. This shot was offered to those aged eighteen to thirty-four in pharmacies from 5 July. Following consultations on vaccine efficacy and a European-wide effort to focus on mRNA vaccines, Ireland ceased deliveries of the Oxford-AstraZeneca and Janssen vaccines in mid August (see Hogan, 2021a).

On 6 March Ireland reached the milestone of half a million vaccine doses administered. At the time this was seen as slow progress, especially when compared to the speed of the vaccine programme in the UK. This slow pace was widely criticised. However, the programme gradually increased in pace, with 90 per cent of all adults fully vaccinated against Covid-19 by late September, one of the highest rates in the EU (see Hogan, 2021a).

In September a booster programme in order to fight waning immunity was started. Initially, there was debate as to the necessity of such a programme. Further, some non-governmental organisations such as the World Health Organisation deemed it immoral to give fully vaccinated populations boosters while large swathes of the world's population, mainly in poorer countries, were unable to access the vaccine. However, amidst mounting evidence of waning immunity and the increasing incidence of Covid-19 within the community, the government began to roll out the booster campaign. The first offers of a vaccine were made in November. By the early days of 2022 all those previously eligible for the vaccine were able to make an appointment for a booster or could attend walk-in clinics run by the Health Service Executive (HSE). By the end of 2021 Ireland had one of the highest uptakes of the booster vaccine in the EU (see Hogan, 2021a; McGreevy, 2021).

\section{Dublin Bay South by-election}

On 27 April the former Minister for Housing, Planning and Local Government, Eoghan Murphy, TD, resigned his Dáil seat in the Dublin Bay South constituency. The date for the by-election to replace Murphy was set for 8 July (see Lehane, 2021).

The election garnered much interest in the media for several reasons. Firstly, polling indicated that Sinn Féin had become the most popular party in the state. Therefore, the election was seen as a method through which Sinn Féin's polling performance could be compared to their performance in an actual election. This was 
reflected in the nomination of Senator Lynn Boylan as their byelection candidate (see Duffy, 2021b). Secondly, Fine Gael did not nominate former Dublin Bay South candidate Kate O'Connell. O'Connell is a former TD and only narrowly missed out on re-election to the Dáil in 2020. In her stead, James Geoghegan was nominated as Fine Gael's candidate (see Hurley, 2021). Geoghegan's nomination proved controversial. He was a founding member of the pro-life party Renua, a party that splintered from Fine Gael over their pro-life stance in the years leading up to the Repeal the Eight Campaign. Geoghegan was also criticised for being insincere on the social values he professed (see O'Connell \& Ryan, 2021). Thirdly, Dublin Bay South is the constituency of the potential future leader of Fianna Fáil, Jim O'Callaghan, TD. A good showing for Deirdre Conroy, the Fianna Fáil candidate, would, for some, bolster his credentials to lead Fianna Fáil in the future (see McNeice, 2021). Fourthly, despite Labour's poor showing in national polls, there was hope for their candidate, Senator Ivana Bacik. A senator in the University of Dublin Seanad constituency, Bacik is a law professor in Trinity College Dublin and has been a high-profile political figure since the 1980s, most notably in the area of abortion rights. Many inside and outside of the Labour Party considered her a strong candidate in the affluent Dublin Bay South constituency (see Hosford, 2021b). Finally, the then Lord Mayor of Dublin, Hazel Chu, was not selected by the Green Party to contest the election. Instead, the party nominated Dublin City Councillor Claire Byrne. Following several high-profile disagreements between Miss Chu and the Green Party, the Lord Mayor's stock had fallen in the party (see McQuinn, 2021a). The campaign issues mapped the salient political issues at the national level, with the most important area being housing.

On 8 July 26,882 valid votes were cast, representing a turnout of 34.7 per cent. With the quota set at 13,442, Senator Bacik was deemed elected after nine counts. She received 30.2 per cent of the vote, with Geoghegan coming in second with 26.2 per cent of first-preference votes, followed by Boylan with 15.8 per cent of first-preference votes. The result was seen as very poor for the three government parties, especially Fianna Fáil and Fine Gael. While Geoghegan came in second, this constituency is traditionally seen as Fine Gael heartland with anything less than a win seen as a disappointment. Conroy received only 4.6 per cent of the vote. This was seen as a large blow to Jim O'Callaghan's leadership credentials. Further, it also indicated the lack of popularity Fianna Fáil had amongst the electorate (see 'Byelection: Dublin Bay South', 2021). 


\section{The Commission of Investigation into Mother and Baby Homes and certain related matters}

In May 2014 the remains of almost 800 babies were found in a mass grave next to the Tuam Mother and Baby Home, Co Galway, which had been run by the Bon Secours nuns. In 2015 the then Minister for Children and Youth Affairs, Dr James Reilly, TD, announced that the government had appointed three commissioners to lead the Commission of Investigation into Mother and Baby Homes and certain related matters to investigate all mother and baby homes in the state, including Tuam. The independent commission was given a $€ 21$ million budget and a three-year deadline (see Moore, 2021).

On 12 January 2021, following much controversy and several extensions, the report was published. The final report detailed that around 9,000 children, one in seven of those born in the eighteen institutions investigated by the commission, had died in them between 1922 and 1988. This was double the rate of infant mortality in the general population during the same time period. The following day, Taoiseach Michael Martin made a formal apology to survivors on behalf of the state (see O'Carroll, 2021).

The commission received much criticism from the public in the wake of the publication of the report. The main area of criticism was the report's finding that there was insufficient evidence of forced adoption and abuse. Those critiquing the report pointed to the testimonial evidence to the contrary. Further, some survivors claimed their testimony had been amended and/or misrepresented. Following the publication of the report, several survivors sought access to their records through subject access requests to the Department of Health. Many of those who viewed their records claimed that the records were inaccurate, with one survivor going so far as to state a letter purportedly written by her was forged. In July survivors Philomena Lee and Mary Harney took two test judicial review cases against the report. The cases sought to quash several of the conclusions presented in the report. These cases are due to be heard in 2022 (see O'Carroll, 2021).

\section{Katherine Zappone controversy}

On 27 July, while the cabinet was meeting, the Irish Examiner broke the story that the former Minister for Children, Katherine Zappone, was to be appointed as a Special Envoy to the UN for Freedom of 
Expression and Human Rights (with a special focus on LGBTQ+ issues). The announcement was followed by a flurry of further reporting which revealed that the role was newly created and had never been publicly advertised or subject to competition. This raised questions about both the selection process and the role itself. Subsequently, it came to light that it was the decision of Minister for Foreign Affairs Simon Coveney, TD, to appoint Zappone to the role, which paid $€ 15,000$ for approximately fifty to sixty days' work. It also emerged that Taoiseach Micheál Martin had not been aware of this appointment prior to the cabinet meeting (see McQuinn, 2021b).

It later transpired that Zappone had texted Minister Coveney several times over the summer requesting updates on the creation of and her appointment to the role. Zappone found herself in more controversy when, on 4 August, the Irish Independent revealed that she had organised an event in the Merrion Hotel with approximately fifty guests in attendance, including Tánaiste Leo Varadkar, TD, and Labour TD Ivana Bacik. Despite the Merrion Hotel, Zappone and Varadkar's assertions otherwise, as well as a later statement by the Attorney General, the event appeared to contravene Covid-19 restrictions. This added to the mounting pressure on Zappone's position as Special Envoy to the UN. On the same day the story about the event broke, Zappone decided to not accept the role. She stated that the 'clear criticism of the appointment' had impacted the legitimacy of the role itself (see McQuinn, 2021b).

Despite Zappone's resignation, the controversy trundled on. On 31 August Minister Coveney appeared at the Oireachtas Committee for Foreign Affairs where he was questioned on the appointment. During the hearing, he stated that Tánaiste Varadkar had not been involved in the appointment of Zappone. After referencing a text he had sent to Varadkar, Coveney stated that he did not keep text messages on his phone for long periods due to data storage limitations. This caused controversy as Coveney had deleted texts relating to the appointment. This was further compounded when Coveney later said that he deleted texts as a security precaution as he had been hacked in the past. On 6 September, in response to a freedom of information request, the Department of Foreign Affairs released over 100 documents relating to Zappone's appointment. The following day, Coveney again appeared before the Oireachtas Committee for Foreign Affairs where he apologised for the 'political fiasco' surrounding the appointment. Zappone was also invited to appear 
before the committee but declined the invitation. As a US citizen and resident, the committee had no power to compel her to appear (see McQuinn, 2021b).

On 15 September, when the Dáil returned from its summer recess, Sinn Féin tabled a vote of no confidence against Minister Coveney. The government parties enforced the whip for the vote. Fianna Fáil TD Mark MacSharry resigned from the Fianna Fáil parliamentary party in order to vote against Coveney. Despite this, Coveney survived the motion, ninety-two votes to fifty-nine (see Duffy, 2021a).

\section{The HSE cyberattack}

On 14 May the HSE suffered a major ransomware cyberattack. This caused all of the HSE's IT systems to shut down nationwide. This was the most significant attack on an Irish state agency and the largest attack against any health service computer system. The attack had a great impact on the operations of the HSE. A significant number of appointments were cancelled while many hospitals had to rely on paper records. Individuals who required a Covid-19 test had to use walk-in testing clinics as referrals could not be made. The private data of 520 patients, some of it sensitive in nature, was released. Despite reports of a ransom in exchange for a return to full functionality being demanded of the HSE, Taoiseach Micheál Martin confirmed that the state would not pay a ransom. By September over 95 per cent of all servers and devices had been restored. In December PwC released a report detailing the attack. This stated that the attackers were in the HSE computer system eight weeks before the attack was initiated. The report identified the HSE's legacy IT system as being particularly vulnerable to cyberattack (see O'Connor, 2021).

\section{The mica redress scheme}

In 2017 the Report of the Expert Panel on Concrete Blocks noted that the presence of 1 per cent muscovite (a form of mica) causes a reduction in concrete's strength by approximately 5 per cent, and that it has relatively poor bond strength with cement paste. The report also stated that the presence of muscovite caused issues during cold weather as the higher levels of moisture causes blocks to lose their integrity during freeze-thaw action. The National Standards Authority of Ireland had applied a 1 per cent limit to the quantity of mica in 
concrete blocks. However, due to serious failures in building regulations, oversight and compliance, a number of homes in Donegal contained cement blocks at a far higher level than the statutory minimum (see Hennessy, 2021).

After a lengthy campaign by impacted homeowners, the Defective Block Scheme was opened for applications in June 2020. The scheme allowed for wall replacement (up to a cost of $€ 49,500$ ) or full demolition (up to a cost of $€ 247,500$ ). The affected homeowners were unhappy with the scheme for several reasons. Chief amongst them was the initial $€ 5,000$ cost of a mica test, which was borne by the homeowner, and secondly many claimed they could not afford to rebuild their homes without a 100 per cent redress. After months of protest, the government agreed to a 100 per cent redress, capped at $€ 420,000$, at a cost of an estimated $€ 2.2$ billion. This new scheme was criticised by both opposition TDs and campaigners, saying that conditions such as the euro limit per square foot meant that, in reality, the redress scheme fell well short of the desired 100 per cent. The controversy continued into 2022 with neither side able to agree on a suitable redress scheme (see Hennessy, 2021).

\section{Helen McEntee}

In late 2020 Minister for Justice Helen McEntee, TD, announced that she was pregnant. This represented the first time that a serving member of the cabinet had been pregnant in the history of the state. Minister McEntee's pregnancy raised several legal and constitutional issues. TDs are not entitled to maternity leave, with the Constitution, Bunreacht na hÉireann, stipulating that TDs must be available for votes at any time with no concession granted for pregnancy. In what was described as a 'sticking plaster' until a more permanent solution could be brought forward, Minister McEntee entered into a paired voting pact with Social Democrat and opposition TD Holly Cairns. Deputy Cairns agreed to abstain from any votes where Minister McEntee was unable to attend due to maternity leave. Meanwhile, Minister for Rural and Community Development and Social Protection Heather Humphreys, TD, and Junior Transport Minister Hildegarde Naughton, TD, oversaw Minister McEntee's portfolio while she retained her cabinet seat. This marked a historic moment for the state as the first sitting member of cabinet availed of maternity leave (see Pogatchnik, 2021). 


\section{The housing crisis and the government's housing plan}

The housing crisis has been a salient political issue for several years. In 2021 the issues surrounding the Irish housing market continued, with house prices rising by an average of 7.7 per cent. Although they remained 21 per cent below the peak of the Celtic Tiger era. Similarly, rental prices rose by an average of 6.8 per cent across the country. Daft.ie, a property website that produces quarterly reports, noted that the number of rental properties listed on its website was at its lowest point since it had begun tracking availability in 2006. The amount was half the previous record low, which was recorded in mid 2019. Throughout the year, homelessness remained a problem (see Hearne, 2022).

It was within this context that the government launched their new housing plan, Housing for All - A new Housing Plan for Ireland, in early September. The plan involved increasing the supply of housing to an average of 33,000 per year over the following decade and would provide a mix of social, affordable and private housing for sale and rent. The plan committed $€ 4$ billion in government spending in each year of the plan. The government parties described this as the most ambitious housing plan in Ireland's history (Department of Housing, Local Government and Heritage, 2021). The plan was heavily criticised by opposition parties, especially Sinn Féin. The party's spokesperson for housing, Eoin Ó Broin, TD, stated that the plan will make no meaningful impact on the housing crisis. In particular, the timeline presented in the plan and the total number of social houses to be delivered were heavily criticised (see Ó Broin, 2021).

\section{Ireland's corporate tax rate}

Ireland's headline corporate tax rate of 12.5 per cent has long been seen as a central component of Ireland's economic policy. Over successive governments, both Fianna Fáil and Fine Gael had considered the tax rate untouchable. However, for many years this rate has come under pressure from other countries who view Ireland's low tax rate as an unfair means to gain a competitive advantage. In July more than 100 countries supported an OECD proposal to set the corporate tax rate at a global minimum of 15 per cent. Ireland did not initially sign up for this change. In October, amid mounting pressure, Ireland agreed to set its corporate tax rate at 15 per cent for all 
companies with a turnover of $€ 750$ million and above. Those businesses with a turnover under the threshold would retain the 12.5 per cent tax rate (see McQuinn et al., 2021).

\section{Political parties and voters' data}

In June it was reported that Sinn Féin party members had pretended to be pollsters to conduct election surveys. On the same day it emerged that Fianna Fáil, Fine Gael and the Green Party had also engaged in a similar practice. Political insiders stated that the practice was widespread. Commentators, however, labelled the practice duplicitous. Following audits, the Data Protection Commissioner (DPC) was satisfied that the practice did not cause any data-related concerns (see Hosford, 2021a).

Concern was also raised over Sinn Féin's Abú database. The database is comprised of the electoral register, the marked electoral register and additional canvass information. The database proved controversial as data may be held by Sinn Féin without voters' knowledge. Further, under GDPR, people are entitled to access their data. There were questions as to whether or not this was possible for this database. The DPC ruled that this database was not illegal but that voters should be made aware of it through canvassing and literature (see Hosford, 2021a).

\section{Political developments in Northern Ireland}

Following the end of the Brexit negotiations and the agreement of the EU-UK Trade and Cooperation Agreement (the Agreement) in 2020, the Northern Ireland Protocol was introduced. The Agreement had led to different trade arrangements between Northern Ireland and the EU and the rest of the UK and the EU. This was agreed as neither side in the negotiations wanted to see a return to a border on the island of Ireland. However, the EU requires certain customs checks and trade controls at external borders. Brexit meant that the border between Ireland and Northern Ireland had become an external EU border. Therefore, it was agreed that while Northern Ireland would no longer be in the single market, EU free movement of goods and EU Customs Union rules would still apply. Part of this deal was that certain customs checks and controls would take place for goods moving from the mainland UK to Northern Ireland. This Agreement proved 
controversial in Northern Ireland with the Unionist community considering it a betrayal.

Following the Agreement and the introduction of the Northern Ireland Protocol, the Democratic Unionist Party (DUP) leader, Arlene Foster, MLA, came under intense scrutiny from her party members. The 'de facto border' was unacceptable to most in the DUP Parliamentary Party and Foster was criticised for trusting the British Prime Minister, Boris Johnson, who had negotiated the deal. Foster's precarious position as leader of the party also came under more pressure when, unlike most of her peers, she abstained from a vote on gay conversion therapy. Twenty-two DUP MLAs and four MPs expressed no confidence in Foster in a letter. On 28 April Foster announced her intention to resign from her position as party leader (see McCormac, 2021). The election for her replacement was held on 14 May. Edwin Poots, MLA, narrowly defeated Sir Jeffrey Donaldson, MLA, by 52.8 per cent to 47.2 per cent. This was the first time the DUP had democratically elected its leader (see Hogan, 2021b).

Interestingly, Foster resigned her post as First Minister of Northern Ireland but was not replaced by Poots. Instead, Poots with the aid of Sinn Féin, in a deal that resolved the issue of the Irish Language Act, supported the candidacy of Paul Givan, MLA. Many DUP MLAs thought this process was rushed and were unhappy with Poots. Despite never having a motion of no confidence tabled against him, Mr Poots felt his position had become untenable and so, twenty-one days after his election, he resigned his position as leader of the DUP (see McClafferty, 2021). Donaldson ran for the position of DUP leader unopposed and was returned without an election (see Rawlinson, 2021).

\section{Economic growth and Budget 2022}

Despite the Covid-19 pandemic, the Irish economy had come into 2021 in a strong position. According to the European Commission, Ireland's forecasted GDP growth was 14.6 per cent (see BurkeKennedy, 2021). Inflation in 2021 ran at 5.5 per cent, the highest level recorded in two decades (see O'Brien, 2022). Following from Budget 2020, which included record government expenditure, commitments were made for further spending and tax cuts worth $€ 1.5$ billion (see 'Donohoe announces $€ 1.5 \mathrm{bn}$ ', 2021). At the year end, unemployment stood at 5.1 per cent. This was down from 6.2 per cent the previous year (see Central Statistics Office, 2021). 


\section{Other significant political events}

At the start of 2021 Ireland took its seat on the UN Security Council following its successful election in 2020. This was the fifth time Ireland had held a seat on the Council since joining the UN in 1955 (see Moore, 2021).

On 1 January Munster Technological University was officially opened as Ireland's newest and second technological university (see Thomas, 2021).

On 11 January the purchase of alcohol with supermarket vouchers as well as a number of multibuy schemes were banned under new legislation that came into effect (see Neville, 2021).

In early February new laws were introduced that prohibited the distribution or publication of intimate images without the consent of the person featured in the images. Committing such an offence carried a maximum seven-year prison sentence (see O'Keefe \& Dunphy, 2021).

On 19 February Ulster Bank confirmed it would exit from the Irish market. The bank, with 1.1 million customers, 2,800 staff and 88 branches, will wind down its operations in the state over the coming years (see Gleeson \& Hancock, 2021). Later in the year KBC Ireland also confirmed its exit from the market, citing onerous capital-to-debt requirements (see Collins, 2021).

The annual St Patrick's Day meeting between the Taoiseach and the President of the United States was held virtually this year due to the high numbers of Covid-19 cases in both countries (see Leahy \& Lynch 2021).

In September President Michael D. Higgins declined an invitation to attend a church service with Britain's Queen Elizabeth to mark Northern Ireland's centenary. The service, which was organised by the leaders of the main Christian churches, was to be held in Armagh at the end of October. He said he declined the invite because the event had become politicised. President Higgins also stated that the title of the service made it 'inappropriate' for him to attend as head of state (Harrison, 2021).

In November, after initial doubts about his attendance following a false-positive Covid-19 PCR result, Minister for the Environment Eamon Ryan, TD, attended the COP26 climate summit in Glasgow (see Staines, 2021).

At year end the Irish Polling Indicator had support for the political parties at 33 per cent for Sinn Féin, 23.2 per cent for Fine Gael and 19.7 per cent for Fianna Fáil. Independent candidates enjoyed a 
10.3 per cent share, while Labour and the Greens had 3.8 and 4 per cent support, respectively. The Social Democrats party was estimated at 2.6 per cent, while Solidarity/People Before Profit was estimated at 2.2 per cent (see Louwerse \& Müller, 2021).

\section{References}

Burke-Kennedy, E. (2021, 11 November). European Commission doubles growth forecast for Irish economy. The Irish Times.

Byelection: Dublin Bay South. (2021). Retrieved from https://www.irishtimes.com/news/elections/dublin-bay-south-byelection [27 January 2022].

Central Statistics Office. (2021). Monthly unemployment. Retrieved from www.cso.ie [27 January 2022].

Collins, S. (2021, 1 December). KBC accounts to move to Bank of Ireland by end-2022. Irish Independent.

Department of Health. (2021). Statement from the National Public Health Emergency Team - Saturday 30 January. Retrieved from www.gov.ie [27 January 2022].

Department of Housing, Local Government and Heritage. (2021). Housing for all - A new housing plan for Ireland. Dublin: Department of Housing, Local Government and Heritage.

Donohoe announces $€ 1.5 \mathrm{bn}$ in extra spending and tax cuts. (2021, 13 October). Retrieved from https://www.rte.ie/news/budget2022/2021/1012/1253129-budget-ireland/ [27 January 2022].

Duffy, R. (2021a, 15 September). Minister Simon Coveney wins confidence vote in the Dáil by 92 votes to 59. Retrieved from https://www.thejournal.ie/ coveney-confidence-vote-5550124-Sep2021/ [27 January 2022].

Duffy, R. (2021b, 2 June). Sinn Féin confirms Lynn Boylan as its candidate for Dublin Bay South by-election. Retrieved from https://www.thejournal.ie/ lynn-boylan-dublin-bay-south-2-5456033-Jun2021/ [27 January 2022].

Gleeson, C., \& Hanock, H. (2021, 29 October). Ulster Bank tells customers to get ready to close accounts. The Irish Times.

Harrison, S. (2021, 17 September). NI100: Michael D Higgins defends decision not to attend centenary event. Retrieved from https://www.bbc.com/news/uknorthern-ireland-58589593 [27 January 2022].

Health Protection Surveillance Centre. (2021). Covid-19 cases in Ireland. Retrieved from HPSC.ie [27 January 2022].

Hearne, R. (2022, 2 January). Rory Hearne: What will 2022 bring for the housing crisis? Irish Examiner.

Hennessy, M. (2021, 15 June). The mica controversy explained: Here's why thousands of people took to the streets of Dublin to protest today. Retrieved from https://www.thejournal.ie/mica-explainer-5467214-Jun2021/ [27 January 2022]. 
Hogan, L. (2021a, 27 December). 'A remarkable story of human endeavour' One year of Covid-19 vaccines. Retrieved from https://www.rte.ie/news/ ireland/2021/1227/1268842-one-year-of-covid-vaccines/ [27 January 2022].

Hogan, L. (2021b, 14 May). Edwin Poots to succeed Foster as new DUP leader. Retrieved from https://www.rte.ie/news/2021/0513/1221492-dupleadership-latest/ [27 January 2022].

Hosford, P. (2021a, 9 July). Q\&A: What is Sinn Féin's Abú database and why is it in the news? Irish Examiner.

Hosford, P. (2021b, 20 December). Right candidate, right constituency, right time for Bacik. Irish Examiner.

Hurley, S. (2021, 10 May). Geoghegan only Fine Gael candidate nominated for by-election. Retrieved from https://www.rte.ie/news/politics/2021/0510/ 1220822-dublin-bay-south-byelection/ [27 January 2022].

Leahy, P., \& Lynch, S. (2021, 15 March). Taoiseach and Biden to hold virtual meeting on St Patrick's Day. The Irish Times.

Lehane, M. (2021, 16 June). Dublin Bay South by-election confirmed for 8 July. Retrieved from https://www.rte.ie/news/2021/0616/1228483-by-electiondate-set/ [27 January 2022].

Louwerse, T., \& Müller, S. (2021). Irish polling indicator. Retrieved from https://pollingindicator.com [27 January 2022].

McClafferty, E. (2021, 17 June). DUP leader Edwin Poots resigns amid internal party revolt. Retrieved from https://www.bbc.com/news/uk-england-essex57521158 [27 January 2022].

McCormack, J. (2021, 28 April). Arlene Foster: Why did the DUP move against its leader? Retrieved from https://www.bbc.com/news/uk-northern-ireland56907858 [27 January 2022].

McGee, H. (2021, 6 January). Covid restrictions Q\&A: What are the latest changes? The Irish Times.

McGreevy, R. (2021, 23 December). Covid: Booster programme to be opened to all as 7,411 new cases reported. The Irish Times.

McNeice, S. (2021, 9 July). Fianna Fáil's Jim O'Callaghan says he 'doesn't have answers today' about why his party performed poorly in this week's Dublin Bay South by-election. Retrieved from www.newstalk.com [27 January 2022].

McQuinn, C. (2021a, 4 June). Byrne named Green Party candidate in Dublin Bay South as Chu loses out. The Irish Times.

McQuinn, C. (2021b, 6 September). Katherine Zappone controversy: Timeline of events. The Irish Times.

McQuinn, C., Horgan-Jones, J., O'Halloran, M., \& Taylor, C. (2021, 7 October). Ireland's corporate tax rate set to rise to $15 \%$, as part of global deal. The Irish Times.

Moore, D. H. (2021). Political developments, 2020. Administration, 69 (1), $1-22$.

Neville, S. (2021, 11 January). Regulations restricting price promotions on alcohol come into place today. Irish Examiner. 
Ní Aodha, G. (2021, 22 October). Coronavirus: 2,466 new cases of Covid-19 confirmed in Ireland. Retrieved from https://www.thejournal.ie/corona virus-cases-22-october-5582116-Oct2021/ [27 January 2022].

O'Brien, C. (2022, 19 January). Consumer prices rise at fastest rate in two decades. The Irish Times.

Ó Broin, E. (2021, 5 September). Eoin Ó Broin: Disingenuous detail makes a mockery of the Housing for All plan. The Business Post.

O'Carroll, S. (2021, 11 June). The explainer: What's next for the Mother and Baby Home Commission? Retrieved from https://www.thejournal.ie/pod cast-explainer-mother-and-by-home-catriona-crowe-5464119-Jun2021/ [27 January 2022].

O’Connell, H., \& Ryan, P. (2021, 10 June). Fine Gael Dublin Bay South candidate James Geoghegan admits he carried out polling for Lucinda Creighton as Renua member. Irish Independent.

O'Connor, N. (2021, 5 May). HSE ransomware attack began on a single computer when an employee clicked on a link. Retrieved from www.thejournal.ie [27 January 2022].

O'Keefe, C., \& Dunphy, L. (2021, 9 February). Coco's Law 'will save other people', says heartbroken mum. Irish Examiner.

Pogatchnik, S. (2021, 11 March). Irish minister's pregnancy raises constitutional questions. Retrieved from https://www.politico.eu/article/irish-ministerspregnancy-raises-constitutional-questions-helen-mcentee/ [27 January 2022].

Rawlinson, K. (2021, 26 June). Sir Jeffrey Donaldson endorsed to lead DUP after majority vote. Retrieved from https://www.theguardian.com/politics/ 2021/jun/26/sir-jeffrey-donaldson-endorsed-to-lead-dup [27 January 2022].

Regan, M. (2021a, 4 December). Fresh restrictions after 'stark' NPHET advice. Retrieved from https:/www.rte.ie/news/coronavirus/2021/1203/1264578ireland-restrictions/ [27 January 2022].

Regan, M. (2021b, 22 July). Indoor dining to resume on Monday for fully vaccinated and those recovered from Covid-19. Retrieved from https://www.rte.ie/news/2021/0721/1236324-indoor-dining-decision/ [27 January 2022].

Ryan, P. (2021, 31 August). Formal social distancing rules gone by Oct 22 and everything else we know about new Covid-19 plan so far. The Irish Times.

Staines, M. (2021, 8 November). Ryan travels to COP26 amid calls for clarity over second COVID test. Retrieved from www.newstalk.com [27 January 2022].

Taoiseach calls on nightlife sector to engage with Govt. (2021, 20 October). Retrieved from https://www.rte.ie/entertainment/2021/1019/1254604-livevenues-nightclubs-return-in-revised-reopening/ [27 January 2022].

Thomas, C. (2021). Creation of new Munster Technological University an 'important milestone' for south west. Retrieved from www.thejournal.ie [27 January 2022]. 